\title{
Isolating Some Pathogenic Bacteria from Packed Milk and Detecting of Formalin in its Components
}

\author{
Zainab Alag Hassan', Ali Aboud Shareef ${ }^{2}$, Majid Ahmed Kadhim ${ }^{3}$, Abdulameer Abdullah Al-Mussawi ${ }^{4}$ \\ ${ }^{1}$ Lecturer / College of Nursing, University of Basrah, Basrah, Iraq, ${ }^{2}$ Assisstant Professor / Department of Biology, \\ College of Education for Pure Sciences, University of Basrah, Basrah, ${ }^{3}$ Assisstant lecturer / Al-Sadr Teaching \\ Hospital, Central Laboratory, Iraq, ${ }^{4}$ Professor / College of Nursing, University of Basrah, Basrah, Iraq
}

\begin{abstract}
Aims: The main aims of thisstudyis to isolate pathogenic bacteria from packed milk in Basrah city, and to detect the presence of formalin in milk samples.

Methodology:A total of 9types of packed milk were collected from the market in different period. The samples were transported to the laboratory in cooling conditions. They were stored in a refrigerator and analyzed within 24 hours. One $\mathrm{ml}$ from each sample was diluted in $9 \mathrm{ml}$ sterile distilled water, the diluted sample was a streak inoculated on chromogenic media. Three $\mathrm{ml}$ of milk sample was taken in a test tube and diluted with equal size of water. $5 \mathrm{ml}$ of sulfuric acid (90\%) were added to the diluted milk slowly to the side of test tube which must handle with slant position in order to form separation layer. In case of formaldehyde presence a violet layer will form. This method detect of 1 part of formaldehyde in 200000 parts of milk

Result: The result showed only Staphylococcus saprophyticus and Staphylococcus aureus have been isolated from milk samples $(23.4 \%)$ and (10.6\%) respectively. The result showed that high temperature not very effective since two pathogenic bacterial species have been isolated and formalin have been detected in milk samples. The result showed no effect of addition of formalin in some sample and did not inhibit the growth of bacteria.
\end{abstract}

Conclusions: This study concludes that most of the packed milk under study contaminated with some pathogenic bacterial species, most of milk samples contained formalin.

Key words: Bacteria, Milk, Formalin, Basrah

\section{Introduction}

Milk and its products have been an important part of the human diet for some 8000 years and are part of the official nutritional recommendations in many countries worldwide. Milk products are rich in calcium, protein, potassium and phosphorus and it is very important for children and adolescents because it contains numerous essential nutrients so itprovides around $52-65 \%$ of the dietary reference intake of calcium and $20-28 \%$ of the protein requirement ${ }^{1,2}$. Some of the bacteria contained in

\section{Corresponding Author}

Zainab Alag Hassan

E-mail id:drzainabA2018@gmail.com

Tel. No: 00964-7718883937 milk (such as Lactobacillus spp or Bifidobacterium spp.) are also present in the healthy human gastrointestinal tract, aiding in digestion and protection from other infections, while other bacteria can be extremely harmful to human health.Milk can be polluted by Mycobacterium bovis, Brucella species, Streptococci and Coxiellaburnettifrom infected cattle. Agents from human sources such as Salmonella species, Shigella species, Corynebacterium diphtheria and Streptococcus species can also be presented in milk ${ }^{3}$.

Many preservatives such as nitrate, boric acid, salicylic acid, hydrogen peroxide, formalin, carbonate and bicarbonate are adding to milk to improve keeping quality of milk and to delay spoilage is a problem for regulatory bodies from the early history of dairying. The toxic effect, hypersensitivity, teratogenic effect 
and carcinogenic effect are the most common serious public health hazard appears as a result of accumulation of preservatives ${ }^{4}$.The addition of Formalinas adulterant in milk affects on the health of consumers; it causes vomiting, diarrhea and abdominal pain. Larger doses may cause decreased body temp, shallow respiration, weak irregular pulse and unconscious. It also affects the optic nerve and cause blindness. It is one of the potent carcinogens ${ }^{5}$. Therefore the present study was performed to throw out a light on the microbiological examination for detecting pathogenic bacteria and formalin detection in packed milk.

\section{Methodology}

\section{Collection of milk products}

Nine types of packed milk were collected from the market in different period. The samples weretransported to the laboratory in cooling conditions. They werestored in a refrigerator and analyzed within 24 hours $^{6}$.

\section{Microbiological analysis}

One $\mathrm{ml}$ of each sample was diluted in $9 \mathrm{ml}$ sterile distilled water. The diluted sample was a streak inoculated on chromogenic media as given below:

*Staphylococcus chromagar (Paris, France) used to isolate Staphylococcusaureusand Staph. Saprophyticus.

*E. coli chromagar (Paris, France) used to isolate
Escherichia coli and other gram negative bacteria.

* Salmonellchromagar (Paris, France) used to isolate Salmonella spp.

* Pseudomonaschromagar (Paris, France) used to isolate Pseudomonasaeruginosa

\section{Detection of formaldehyde presence}

Three $\mathrm{ml}$ of milk sample was taken in a test tube and diluted with equal size of water. $5 \mathrm{ml}$ of sulfuric acid $(90 \%)$ were added to the diluted milk slowly to the side of test tube which must handle with slant position in order to form separation layer. In case of formaldehyde presence a violet layer will form. This method detect of 1 part of formaldehyde in 200000 part of milk ${ }^{7}$.

\section{Results}

The recent study was detected of pathogenic bacteria(Escherichia coli, Salmonella typhi, Staphylococcus aureus,Staphylococcus saprophyticus and Pseudomonas aeroginosa) in packed milk samples from different origin of products in more than one date of production (November 2018 to February 2019). Only,S. saprophyticus and $S$. aureus have been isolated from milk samples $(23.4 \%)$ and $(10.6 \%)$ respectively. The CFU number of $S$. aureus and S. saprophyticus isolated from milk samples was documented in Table 1.

Table 1: number of bacterial colony forming unit (CFU) on chromo agar media

\begin{tabular}{|c|c|c|c|}
\hline \multirow{2}{*}{ Type of sample/origin of product } & \multirow{2}{*}{ No. of samples } & \multicolumn{2}{|c|}{ Number of CFU } \\
\hline & & S. aureus & S. saprophyticus \\
\hline Safio /KSA & 1 & & Uncountable \\
\hline \multirow{3}{*}{ Almarai/ KSA } & 1 & 1 & \\
\hline & 2 & & 1 \\
\hline & 3 & & 1 \\
\hline \multirow{6}{*}{ KDD/ Kuait } & 1 & 2 & 6 \\
\hline & 2 & Uncountable & \\
\hline & 3 & & 1 \\
\hline & 4 & & 3 \\
\hline & 5 & & Uncountable \\
\hline & 6 & & 1 \\
\hline \multirow{3}{*}{ Kalleh /Iran } & 1 & 1 & \\
\hline & 2 & & 1 \\
\hline & 3 & & 1 \\
\hline
\end{tabular}


All samples under study have been written on its packet "sterilized by high temperature" and no added preservative was mentioned. However, the result showed that high temperature not very effective since two pathogenic bacterial species have been isolated and formalin have been detected in milk samples (Table 2).In some samples, the addition of formalin to milk also did not inhibit the growth of bacteria.

The lack of mention of the ingredients of any particular food products, especially the presence of preservatives is a commercial fraud.

Table 2: Number of milk samples contain formalin

\begin{tabular}{|l|l|l|l|}
\hline Sr.No. & $\begin{array}{l}\text { Type of sample / } \\
\text { origin of product }\end{array}$ & $\begin{array}{l}\text { Total } \\
\text { number } \\
\text { of } \\
\text { samples }\end{array}$ & $\begin{array}{l}\text { No. of the } \\
\text { samples } \\
\text { contain } \\
\text { formalin }\end{array}$ \\
\hline 1 & Safio /KSA & 8 & 2 \\
\hline 2 & Almarai/ KSA & 8 & 8 \\
\hline 3 & KDD/ Kuait & 11 & 11 \\
\hline 4 & Kalleh /Iran & 6 & - \\
\hline 5 & Farms alsaba/Syria & 3 & - \\
\hline 6 & Tiffany /UAE & 6 & 3 \\
\hline 7 & Nesquik/ Turky & 2 & 2 \\
\hline 8 & Alis / Iran & 2 & 2 \\
\hline 9 & Nada/ KSA & 1 & 1 \\
\hline
\end{tabular}

\section{Discussion}

Iraq relies heavily on imported products, so that there was no Iraqi milk available during the collection of samples from the market. There are Iraqi products of yogurt and cheese, but not packaged milk. The packaged milk found in the Iraqi markets is a Saudi, Kuwaiti, Turkish, Iranian, UAE and few Syrian ones. Since, the war in Syria have been started, Syrian products decreased in Iraqi markets. Formaldehyde is quickly absorbed from the gastrointestinal tract following ingestion and quickly diffuses into many tissues, including the brain, testis, and liver ${ }^{8}$ which makes it a dangerous chemical to be used as preservative ${ }^{9,10}$.Toxicological effects including histopathological alteration in the stomach (i.e., gastrointestinal lesions (such as papillomata's hyperplasia and hyperkeratosis), allergy, asthma ${ }^{11}$, abdominal pain and vomiting.

A Bangladesh study showedsome severe histological alterationsin liver and kidney in treated mice, which werefed with formalin as $30 \mu \mathrm{l}, 3 \mu \mathrm{l}$ and $0.3 \mu$ lfor 30 days ${ }^{12}$.Formalin is significantly related with cancer, particularly nasopharyngeal cancer in humans through inhalation during occupational exposure ${ }^{13}$.Sometimes caused gastrointestinal cancer when present withhigh concentration in drinking water ${ }^{14}$.Consumption of foods contaminated with this dangerous chemical exposes humans, particularly kids and elderly to severe health problems in Iraq and some developing countries.We conclude that most of the packed milk under study contaminated with some pathogenic bacterial species, most of milk samples contained formalin.

Ethical Clearance:Ethical clearance taken from nursing college/university of Basrah.

\section{Funding Source:Self}

\section{Conflict of Interest: Nil}

\section{References}

1. Vissers PA, Streppel MT, Feskens EJ, de Groot LC. The contribution of dairy products to micronutrient intake in the Netherlands. J Am CollNutr.2011, 30:415-421.

2. Skinner ML, Simpson JA, Buchholz AC. Dietary and total calcium intakes are associated with lower percentage total body and truncal fat in young, healthy adults. J Am CollNutr.2011;30(6):484-490.

3. Anderson $\mathrm{M}$, Hinds $\mathrm{P}$, Hurditt $\mathrm{S}$, Miller $\mathrm{P}$, McGrowder D, Alexander-Lindo R. The microbial content of unexpired pasteurized milk from selected supermarkets in a developing country. Asian Pac J Trop Biomed; 2011, 1(3): 205-211.

4. Amin MA. Studies on the effect of some preservatives on milk and some dairy products. M. Sc., Thesis Fac. Agric., El-Fayoum, Cairo Univ., Egypt.2002.

5. Gwin MC, Lienert G, Kennedy J. Formaldehyde exposure and asthma in children.A systematic review. Environ Health Perspect2009, 118: 313317.

6. Patil SS, Zagare MS, Ghorade IB, Deshmukh AM. Isolation of pathogens from dairy products and effect of temperature on pathogens. Paripex- Indian 
Journal of Research. 2014, 3: 76-79.

7. Acree SF. Formaldehyde in milk: Preliminary. J. Biol. Chem. 1906, 2:145-148.

8. Smith AE. Formaldehyde, Occup Med, 1992, 42, 83-88.

9. Agency for Toxic Substances and Disease Registry (ATSDR) Toxicological profile for formaldehyde. US department of health and human services. Atlanta, US.1999.

10. International Programme on Chemical Safety (IPCS). Formaldehyde. Environmental Health Criteria, WHO, Geneva, 1989, 89.

11. Rumchev KB, Spickett JT, Bulsara MK, Phillips MR, Stick SM. Domestic exposure to formaldehyde significantly increases the risk of asthma in young children. Eur. Respir. J.,2002, 20:403-408.
12. Mamun MA, Rahman MA, Zaman MK, Ferdousi Z, Abu Reza M. Toxicological effect of formalin as food preservative on kidney and liver tissues in mice model. Journal of Environmental Science, Toxicology and Food Technology (IOSRJESTFT).2014, 8(9): 47-51.

13. Hayes RB, Raatgever JW, De Bruyn A, Gerin M. Cancer of the nasal cavity and paranasal sinuses, and formaldehyde exposure. Int J Cancer, 1986, 37, 487-492.

14. Takahashi M, Hasegawa R, Furukawa F, Toyoda K, Sato H, Hayashi Y.Effects of ethanol, potassium metabisulfite, formaldehyde and hydrogen peroxide on gastric carcinogenesis in rats after initiation with N-methyl-N'-nitro-N-nitrosoguanidine. Japanese Journal of Cancer Research. 1986, 77, 118-124. 